DOI: 10.1515/LPTS-2015-0009

\title{
ASSESSMENT OF WIND SHEAR AND WIND ENERGY POTENTIAL IN THE BALTIC SEA REGION OF LATVIA
}

\author{
V. Bezrukovs ${ }^{1,2}$, V1. Bezrukovs ${ }^{2}$, A. Zacepins ${ }^{1}$, \\ V. Komashilovs ${ }^{1}$ \\ ${ }^{1}$ Institute of Physical Energetics \\ 21 Aizkraukles Street, Riga, LV-1006, LATVIA \\ ${ }^{2}$ Ventspils University College \\ 101 Inzenieru Street, Ventspils, LV-3601, LATVIA \\ elmag@inbox.lv
}

\begin{abstract}
The paper is devoted to the investigation into the wind energy potential based on long-term observations of the wind speed and energy density fluctuations at heights from 10 to $160 \mathrm{~m}$ on the Baltic Sea coast of Latvia. During the observations (2004 - 2013), the wind speed and direction values were measured, and the statistical database was accumulated using a LOGGER 9200 Symphonie measuring systems mounted on $60 \mathrm{~m}$ masts - one on the western coast and another on the north-east of Latvia. From June 2011 to May 2012, these measurements were complemented with the data for the heights from 40 to $160 \mathrm{~m}$ obtained by means of a ZephIR lidar and with the metrological data provided by "Latvian Environment, Geology and Meteorology Centre" for the same period. The graphs of seasonal fluctuations in the wind speed were obtained for the heights up to $160 \mathrm{~m}$ by measurements over the period of 2007 2013. The results of the research on the wind speed distribution up to $200 \mathrm{~m}$ are promising for evaluation of the wind energy potential of Latvia and will be helpful in assessment of prospective sites for construction of WPPs.
\end{abstract}

Keywords: long-term wind measurements; wind speed and energy distribution up to $200 \mathrm{~m}$; ZephIR lidar; LOGGER 9200 Symphonie; wind speed approximating functions.

\section{INTRODUCTION}

Systematic long-term measurements of wind speeds in Latvia taking into account the wind speed distribution at several heights have been carried out since 2007 at two sites on the north-west coast of the Baltic Sea in the Ventspils region (sites 1 and 3 in Fig.1) and on the north of the country in the Matishi region (site 2), 35 $\mathrm{km}$ from the sea shore [1]. Sites 1, 2, 3 where the meteorological equipment is located are shown on the map of Fig. 1 by stars. By circles on the map the locations of State MetStations are marked which are keeping long-term observations of the wind speed. 
The previous investigations pursued with the aim to estimate the wind energy potential (using the relevant database made up by the "Latvian Environment, Geology and Meteorology Centre") relate to the measurement height of $10 \mathrm{~m}$ above sea level. However, taking into account the Latvian topography with large territories covered by massive forests, for commercial purposes it is possible to use only the energy supplied by winds at heights $30-40 \mathrm{~m}$.

So far, in Latvia no systematic long-term measurements with gathering the relevant information have been carried out for the wind speeds at these heights and above.

At the same time, the results of long-term measurements of the wind speed that are stored in the database of MetStations provide valuable information based on which, with appropriate calibration of extrapolation coefficients, the annual average wind speed at a height up to $150 \mathrm{~m}$ could be calculated. This would allow a precise enough estimation of the potential of wind energy resource in a particular territory. The measurements of wind speed at sites 1 and 2 were carried out using certified sensors of wind speed and sensors indicating the direction of air stream. The measuring sensors are arranged on metallic masts (53 and $60 \mathrm{~m}$ above ground) at several levels $[2]$.

For storing the information from sensors at all height levels, an NRG LOGGER Symphonie 9200 measuring complex was used. The complex has an independent energy supply from batteries and stores on its flash memory card the average wind speed values in every $10 \mathrm{~min}$.

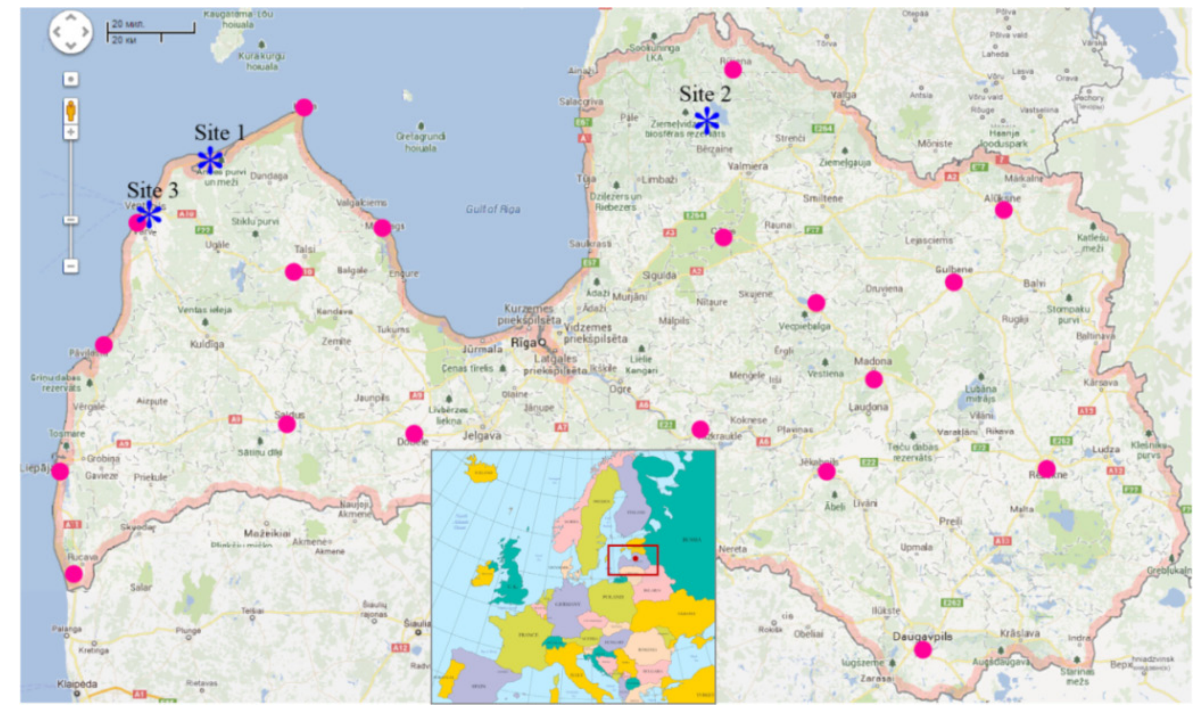

Fig. 1. Map of Latvia with location of the wind speed measurement sites 1, 2 and 3 (stars) and State MetStations (circles)

Retrieval and filtering of the wind data from both the sites were done by an NRG Symphonie Data Retriever. Further data analysis was made using Microsoft Excel with additional scripts, WRPLOT View - Lakes Environmental Software and Natural Power Software. Another option for the data analysis and wind data storage was the use of a developed web system designed for this purpose [3]. The installation 
of the $60 m$ high mast with the Symphonie measuring complex fixed to it is shown in Fig. 2.

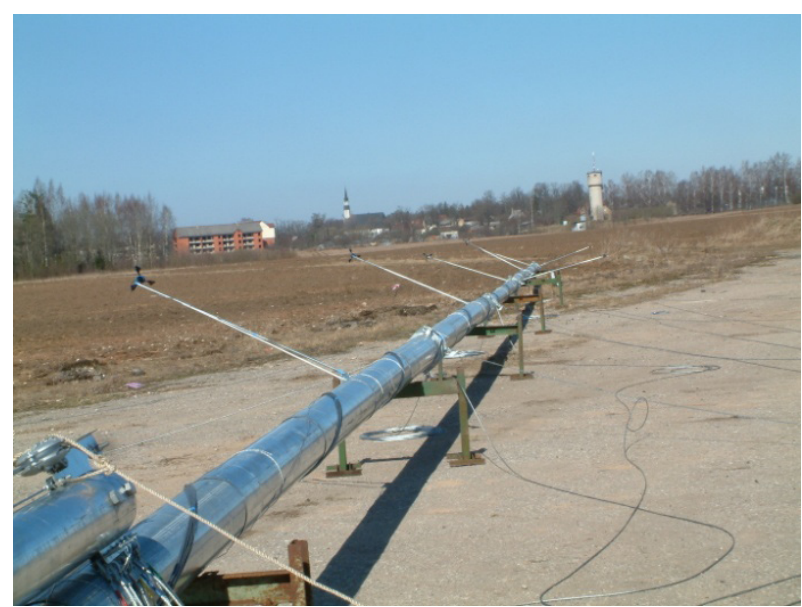

Fig. 2. Installation of the $60 \mathrm{~m}$ high mast with a measuring complex Symphonie (site 2, Matishi)

At site 3, for measuring the wind speed an optical remote sensing complex ZephIR is used, which measures the wind speed and direction at a distance. The complex (see Fig. 3) is installed on the top floor of an eight-story apartment building, and has a direct connection to the power grid and internet.

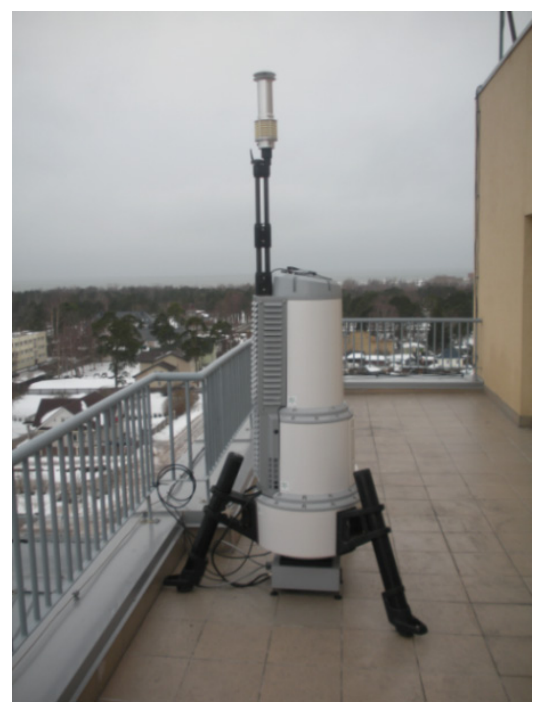

Fig. 3. Optical remote sensing complex ZephIR for measuring wind speed and direction at a distance up to height $160 \mathrm{~m}$ on five height levels (Ventspils, site 3 near the Baltic Sea shore

Site 3 is located $800 \mathrm{~m}$ from the sea shore, at an elevation of $42 \mathrm{~m}$ above the Baltic Sea level. Figures 4 and 5 show the interface of wind speed measurement complex ZephIR for configuration of the height levels, and the results of measuring the wind speed with a three-second integration for each height, which highlights the process of forming a pattern for the wind speed distribution in dependence on the time of measurements. 


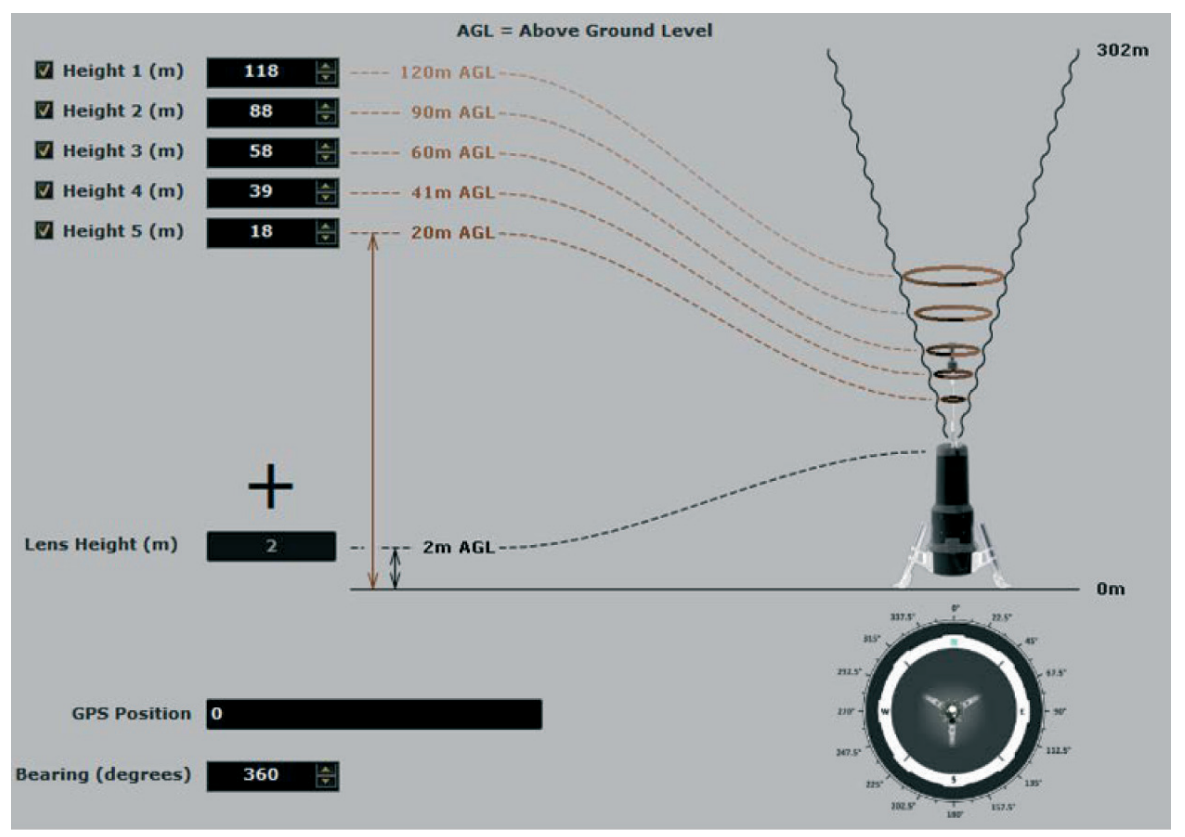

Fig. 4. The user interface of Waltz software applied to configuration of the height levels for the wind speed measuring complex ZephIR

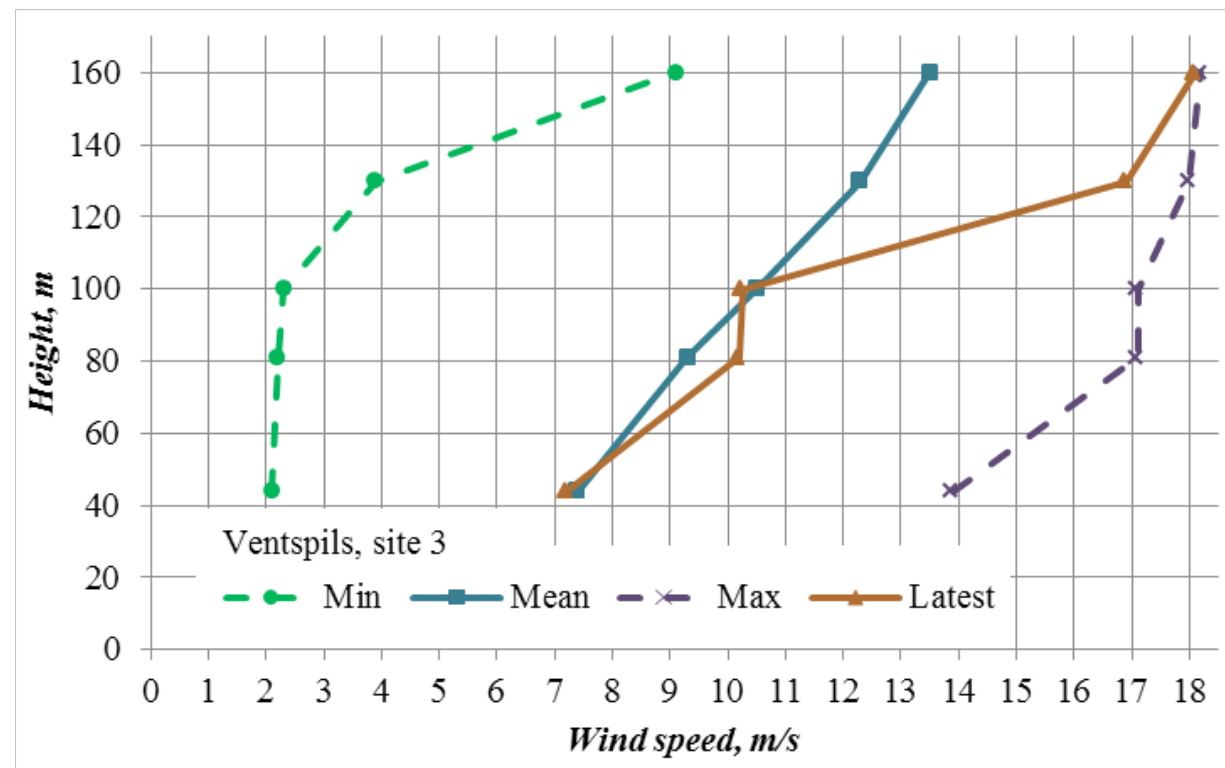

Fig.5. Wind shear at heights from $44 \mathrm{~m}$ to $160 \mathrm{~m}$ obtained in a short time span $(24 \mathrm{~h})$ using the complex ZephIR software. The curves are updated in real time and correspond to the minimum, maximum, mean and latest wind speeds for all levels

The Wind Rose derived from the complex ZephIR data for $160 \mathrm{~m}$ height in the measurement time $T(06.2011 / 05.2012)$ is shown in Fig. 6. From the diagram it could be seen that the main energy stream is brought by south-west winds from the Baltic Sea side, with the average wind speed at a height of $160 \mathrm{~m}$ being $V_{\text {avg. }}=9.91, \mathrm{~m} / \mathrm{s}$. 


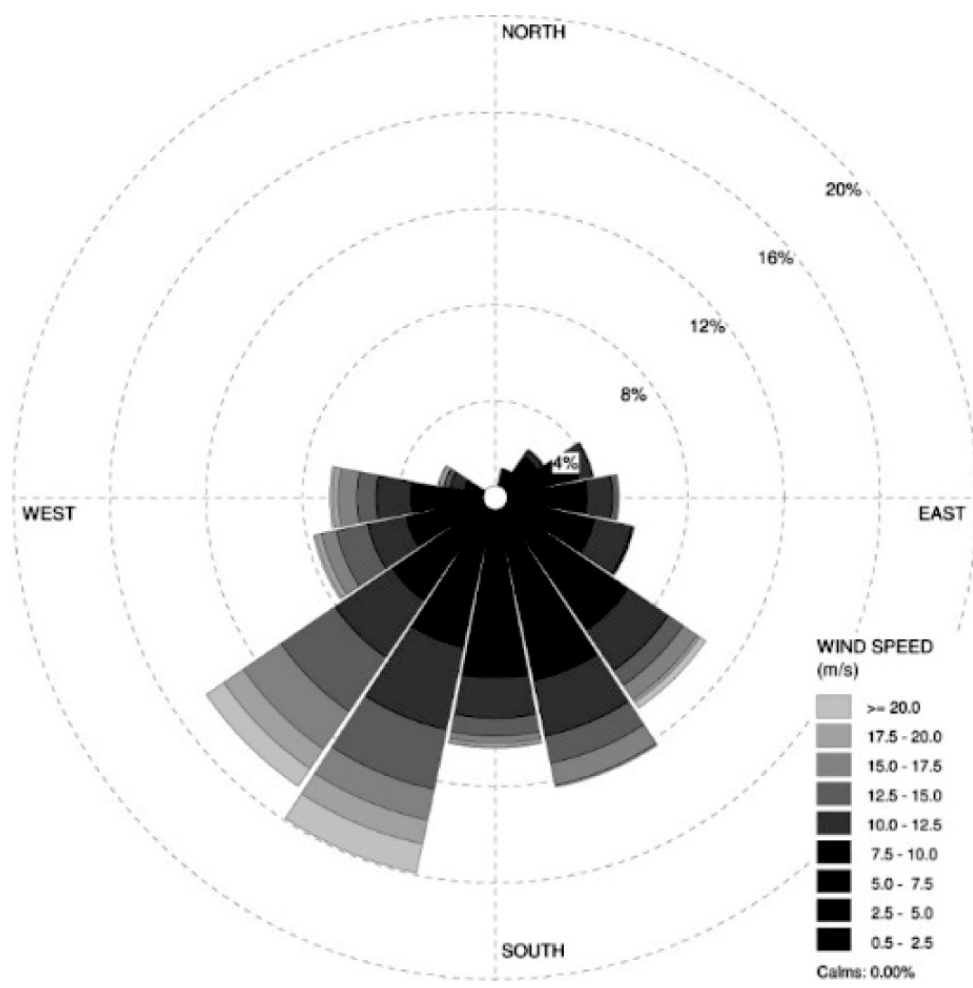

Fig. 6. Wind Rose from measurement complex ZephIR data at the height $160 \mathrm{~m}$ for measurement time $T(06.2011 / 05.2012)$

\section{INVESTIGATION INTO FLUCTUATIONS IN THE AVERAGE WIND SPEED VALUES}

The charts of seasonal fluctuations in the average wind speed $V_{\text {avg. }} \mathrm{m} / \mathrm{s}$ at heights 20, 30, $50 m$ (site 1) and 10, 30, $60 \mathrm{~m}$ (site 2) are shown in Figs. 7 and 8, for monthly averaged measurement time $T(07.2007 / 11.2012)$ and $(04.2009 / 04.2013)$, respectively.

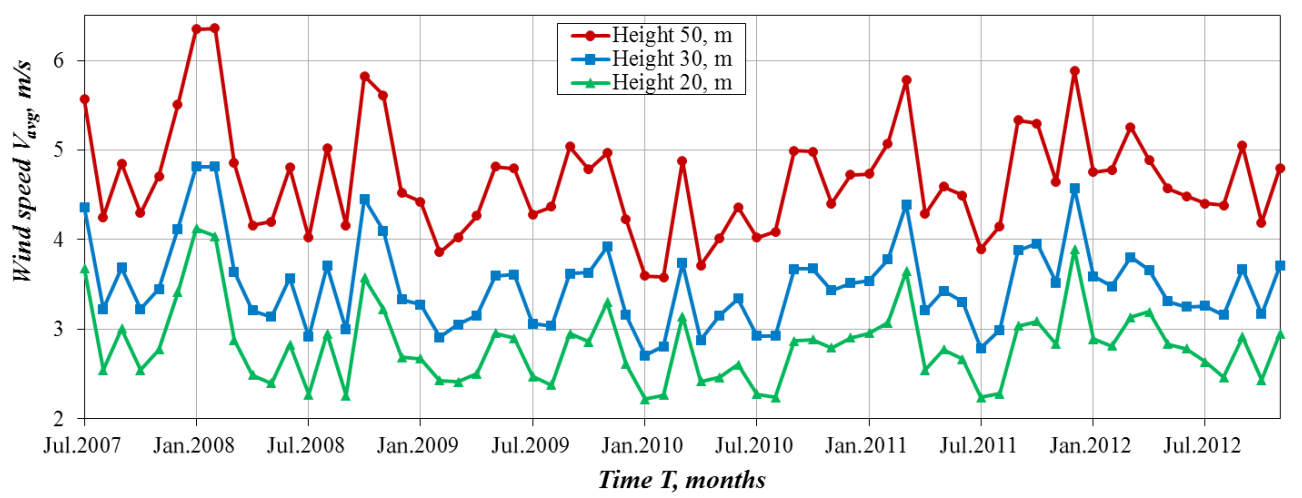

Fig. 7. Average wind speed $V_{\text {avg. }}$ for measurement time $T(07.2007 / 11.2012)$ at heights 20,30 and 50 $m$ (site 1 , Ventspils) 


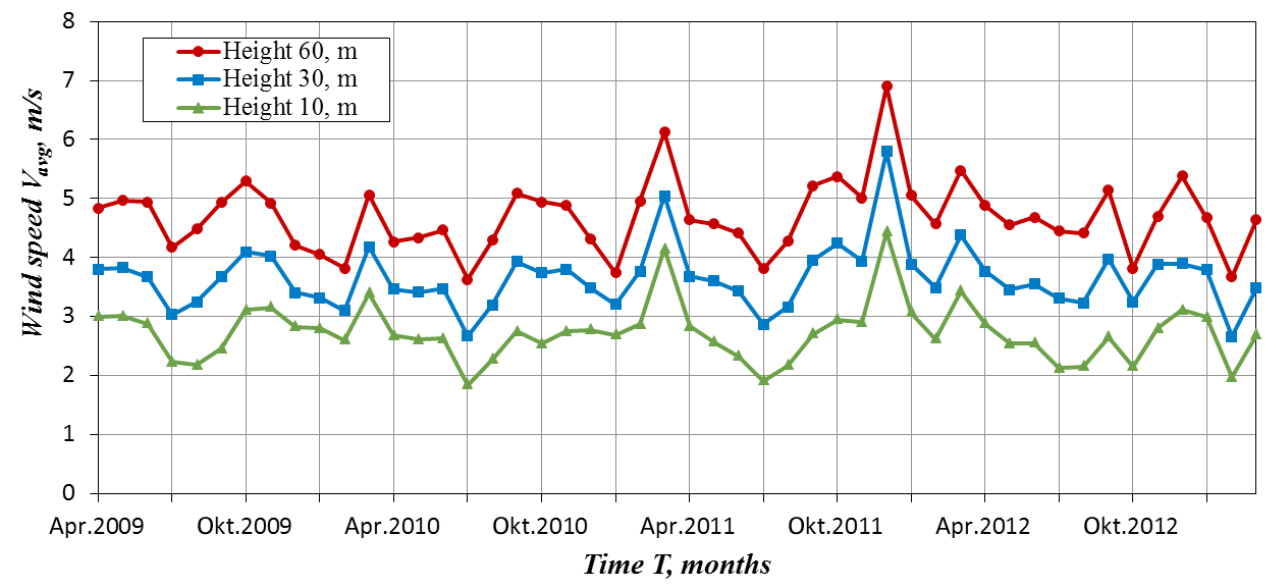

Fig. 8. Average wind speed $V_{\text {avg. }}$ for measurement time $T(04.2009 / 04.2013)$ at heights 10,30 and $60 \mathrm{~m}$ (site 2, Matishi)

Figure 9 shows the curves of wind speed variations for time $T$ (27.06.2011/ 08.05.2012), site 3, obtained using the data of MetStation for height $20 \mathrm{~m}$ and of complex ZephIR for heights 100, 130 and $160 \mathrm{~m}$ above the Baltic Sea level. On the diagram, a good agreement is seen for the wind speed values obtained by two measuring systems at different heights.

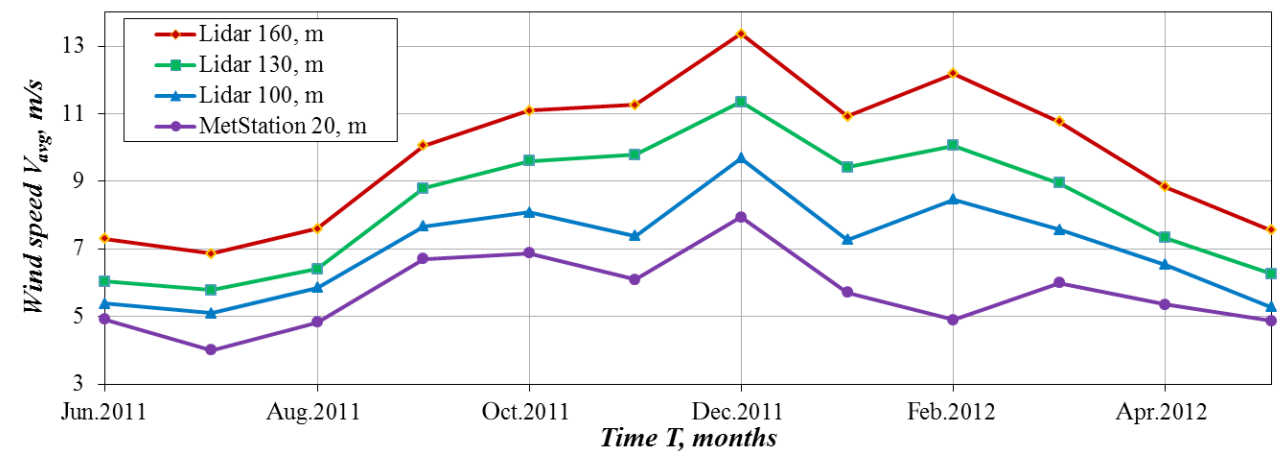

Fig. 9. Average wind speed $V_{\text {avg. }}$ for measurement time $T$ (27.06.2011/08.05.2012). The data from MetStation database for height $20 \mathrm{~m}$, and from complex ZephIR for heights 100, 130 and $160 \mathrm{~m}$ (site 3, Ventspils).

From analysis of the statistical data reported in [1] it follows that the curve of average long-term wind speed $V_{\text {avg.h }}$ distribution in height $h$ is well approximated by the power law function:

$$
V_{\text {avg.h }}=V_{\text {avg.ref. }} \cdot\left(\frac{h}{h_{\text {ref. }}}\right)^{\alpha}
$$

where $V_{\text {avg.ref. }}$ is the value of the average long-term wind speed at the height of measurement $h_{\text {ref. }}$, and $\alpha$ is the approximation coefficient. 
Similarly, to approximate the curve of height distribution for the average cubic long-term wind speed values $V_{\text {avg.cub.h }}$ the following expression could be used:

$$
V_{\text {avg.cub.h }}=V_{\text {avg.cub.ref. }} \cdot\left(\frac{h}{h_{\text {ref. }}}\right)^{\beta}
$$

where $V_{\text {avg.cub.ref. }}$ is the average cubic long-term wind speed at the height of measurement $h_{\text {ref. }}$, and $\beta$ is the respective approximation coefficient.

Figures 10 and 11 display, respectively, the curves of height $h$ distribution for the average long-term wind speed values $V_{a v g . h}$ and the curve of such distribution for the average cubic long-term wind speed $V_{\text {avg.cub.h }}$. The models are calculated for up to the height of $200 \mathrm{~m}$ using expressions (1) and (2) based on the measurement data and extrapolation coefficients. These latter are presented in Table 1 and correspond to three different types of terrain at sites 1, 2 and 3 [4], with the root-mean-square deviation $R^{2}$ of the approximating curves not less than 0.985 .

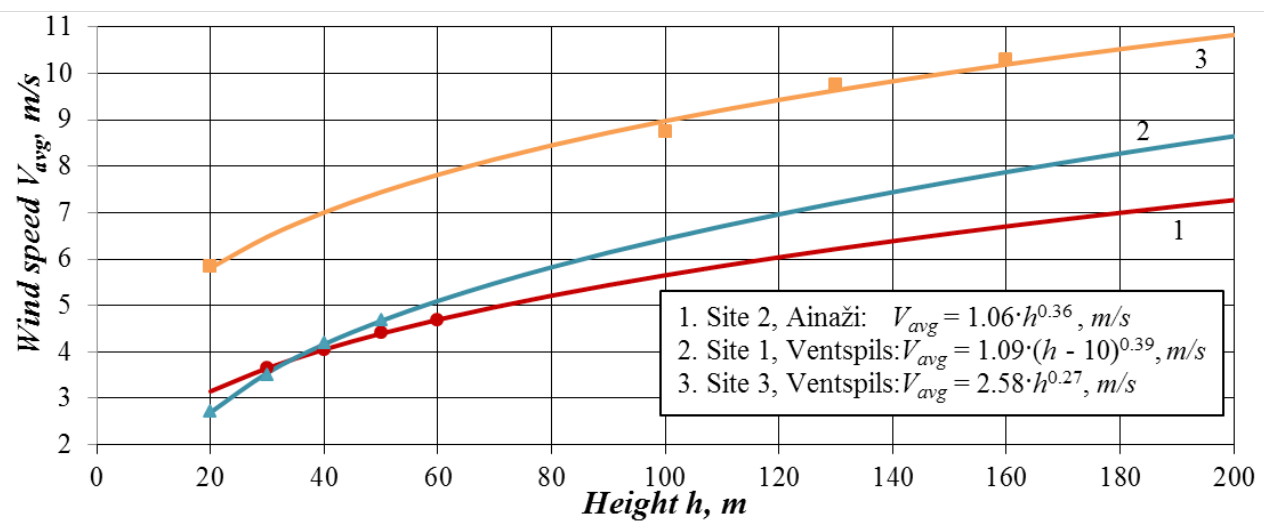

Fig. 10. The average long-term wind speed $v s$. height, $V_{\text {avg. }} h=f(h)$, for sites 1,2 and 3 extrapolated the height up to $200 \mathrm{~m}$ using power law relationship (1).

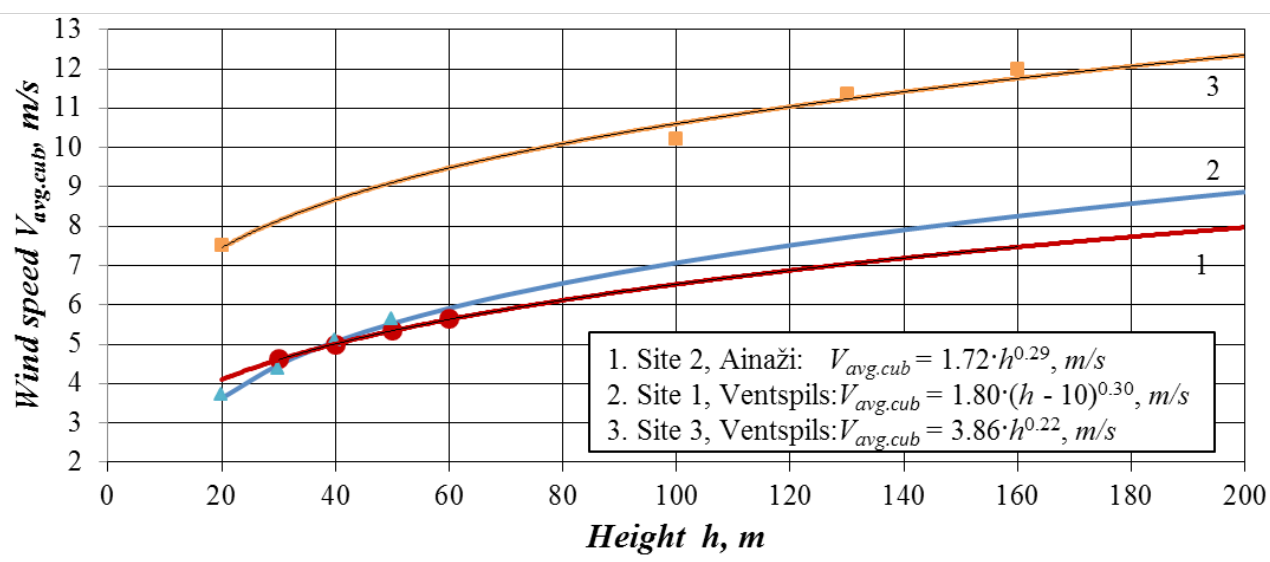

Fig. 11. The average cubic long-term wind speed vs. height, $V_{\text {avg.cub.h }}=f(h)$, for sites 1,2 and 3 extrapolated the height up to $200 \mathrm{~m}$ using power law relationship (2). 
The determination of approximation coefficients for the height distribution curve of average wind speed values which was done within a relatively short time span with the use of measuring complexes (a mast with sensors or a lidar) allows future calculations of the wind speed at a given height based on the long-term measurement data from MetStations for the height of $10 \mathrm{~m}$. Therefore - which is important - the data obtained for this height at many points in the territory of Latvia can be used to draw the map of potential wind energy at heights up to $200 \mathrm{~m}$.

Table 1 .

Long-term average ( $\left.V_{\text {avg.ref }}\right)$ and average cubic $\left(V_{\text {avg.cub.ref }}\right)$ wind speed values at the height of measurements $h_{r e f}$, and coefficients $\alpha$ and $\beta$ corresponding to three types of terrain

\begin{tabular}{|c|c|c|c|c|c|c|c|c|}
\hline Site & Terrain description & $\begin{array}{c}h_{r}, \\
\mathrm{~m}\end{array}$ & $\begin{array}{c}V_{\text {avg.r }}, \\
\mathrm{m} / \mathrm{s}\end{array}$ & $\alpha$ & $\mathrm{R}^{2}$ & $\begin{array}{c}V_{\text {avg.cub.r }}, \\
\mathrm{m}\end{array}$ & $\beta$ & $\mathrm{R}^{2}$ \\
\hline 1 & Forest and woodlands & 20 & 2.71 & 0.39 & 0.9983 & 3.69 & 0.30 & 0.9875 \\
\hline 2 & Few trees and crops & 30 & 3.65 & 0.36 & 0.9989 & 4.62 & 0.29 & 0.9987 \\
\hline 3 & Blown sea & 20 & 5.67 & 0.27 & 0.9952 & 7.50 & 0.22 & 0.9852 \\
\hline
\end{tabular}

Continuous records of the wind speed values with a three-second interval make it possible to construct precisely enough the wind speed frequency distribution curves $F(V)[5,6]$, and consequently calculate the wind energy density $P_{\text {avg. }}$ using the known relationships [7]. In Fig. 12, the wind speed frequency distribution curves for site 1 are presented which are constructed based on the factual values of wind speed $\mathrm{V}, \mathrm{m} / \mathrm{s}$ in the time of $07.2007 / 12.2012$.

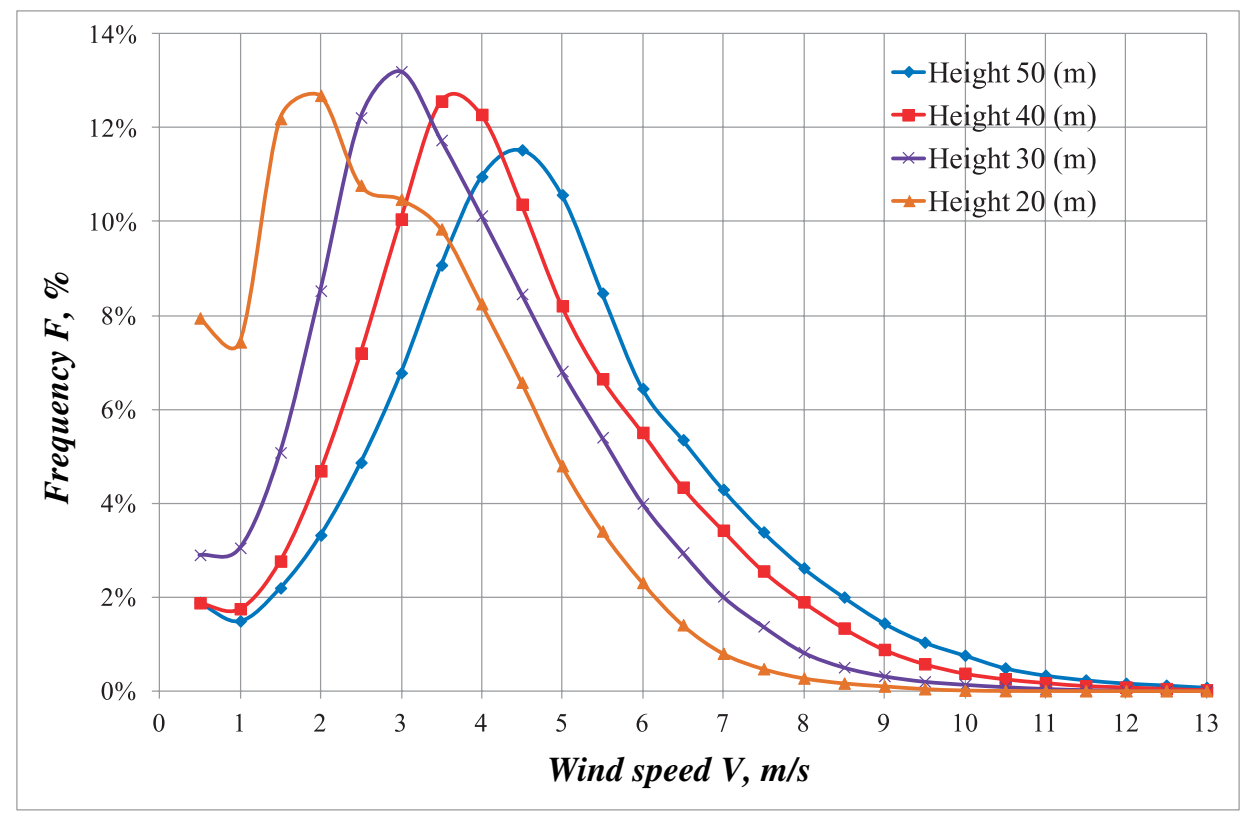

Fig. 12. Wind speed frequency distribution curves $F(V)$ for the time span $07.2007 / 12.2012$ (site 1,Ventspils) 
Figure 13 shows similar curves of the Weibull probability density function $F(V)$ for site 1 for the same time span constructed by the classical method [7] with the use of Weibull's distribution parameters $k$ and $c$. For these functions, appropriate wind energy densities $P_{\text {avg. Weibull }}$ have been calculated.

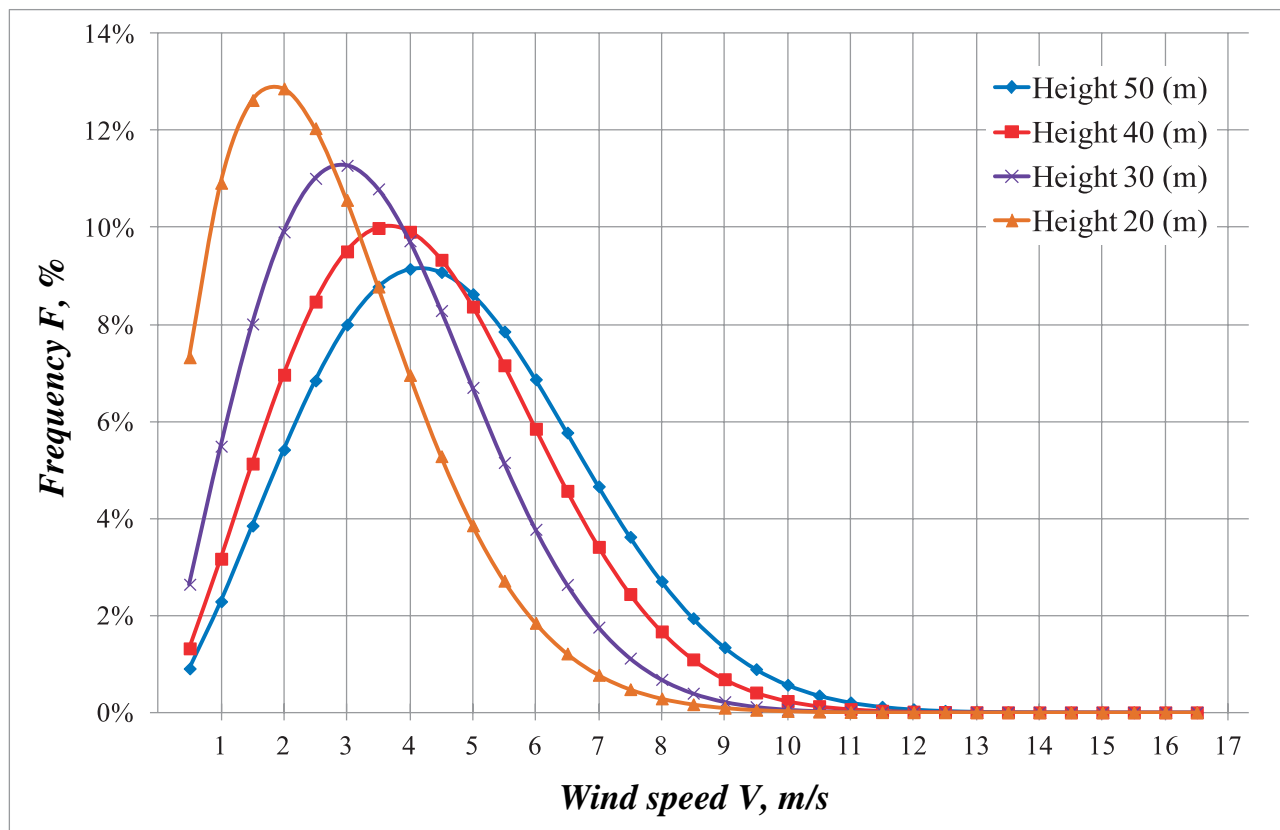

Fig. 13.Weibull's probability density function $F(V)$ for the time $07.2007 / 12.2012$ (site 1, Ventspils)

Table 2 shows the average $V_{\text {avg. }}$ and the average cubic $V_{\text {avg.cub. values of wind }}$ speed along with the calculation results for the wind energy densities $P_{\text {avg. }}$ and

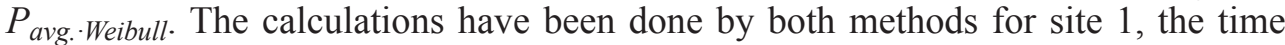
spans $06.2011 / 12.2012$ and $07.2007 / 12.2012$, the heights $20,30,40$ and $50 \mathrm{~m}$ as well as for sites 2, 3, the time spans 04.2009/04.2013 and 06.2011/05.2012, the heights $10,20,30,40,50,60 \mathrm{~m}$ and 44, 60, 80, 81,100,130, $160 \mathrm{~m}$ respectively. The ratio of the wind energy densities, $P_{\text {avg. }} / P_{\text {avg. Weibull }}$, evidences that these values - calculated independently of the measurement height and duration - exceed those calculated based on the Weibull distribution model more than by $10 \%$ on average.

The values of average cubic wind speed $V_{a v g . c u b}$. are calculated taking into account the wind speed frequency distribution for the measured time and are therefore proportional to the medium-range wind energy flow within this period. It was found that the average cubic wind speeds $V_{\text {avg.cub. }}$ consistently exceed the $V_{\text {avg. }}$ values - by $25 \%$ on average, independently of the measurement duration and site. 
Average data for wind speed and energy density in the Ventspils and Matishi regions for measurement heights $20,30,40,50 m$ (site 1), 10, 20, 30, 40, 50, $60 m$ (site 2), and $44,60,80,81,100,130,160 m$ (site 3 )

\begin{tabular}{|c|c|c|c|c|c|c|c|c|c|c|}
\hline \multirow{2}{*}{$\begin{array}{l}\text { Period of } \\
\text { measu- } \\
\text { rement }\end{array}$} & \multirow{2}{*}{$\begin{array}{c}\text { Height } \\
\text { above } \\
\text { ground, } \\
\mathrm{m}\end{array}$} & \multirow{2}{*}{$\begin{array}{l}V_{\text {avg. }} \\
\mathrm{m} / \mathrm{s}\end{array}$} & \multirow{2}{*}{$S D$} & \multirow{2}{*}{$\begin{array}{c}V_{\text {avg.cub. }} \\
\mathrm{m} / \mathrm{s}\end{array}$} & \multirow{2}{*}{$\frac{V_{\text {avg.cub. }}}{V_{\text {avg. }}}$} & \multicolumn{2}{|c|}{$\begin{array}{c}\text { Weibull } \\
\text { parameter }\end{array}$} & \multirow{2}{*}{$\begin{array}{l}P_{\text {avg. Weibull }} \\
\quad W / m^{2}\end{array}$} & \multirow{2}{*}{$\begin{array}{l}P_{\text {avg. }} \\
W / m^{2}\end{array}$} & \multirow{2}{*}{$\frac{P_{\text {avg. }}}{P_{\text {avg. Weibull }}}$} \\
\hline & & & & & & $k$ & $c$ & & & \\
\hline \multicolumn{11}{|c|}{$\begin{array}{l}\text { Site 1, Ventspils. Metrological mast, } \\
\text { 6-month time }\end{array}$} \\
\hline \multirow{4}{*}{$\begin{array}{l}06.2011 / \\
12.2011\end{array}$} & 20 & 2.92 & 1.05 & 3.95 & 1.36 & 1.76 & 3.28 & 33.63 & 37.96 & 1.13 \\
\hline & 30 & 3.64 & 1.04 & 4.67 & 1.28 & 2.06 & 4.11 & 54.99 & 62.65 & 1.14 \\
\hline & 40 & 4.38 & 1.04 & 5.45 & 1.24 & 2.27 & 4.95 & 88.12 & 99.53 & 1.13 \\
\hline & 50 & 4.88 & 1.03 & 6.01 & 1.23 & 2.33 & 5.51 & 119.46 & 133.18 & 1.11 \\
\hline Average & & & & & 1.27 & & & & & 1.13 \\
\hline \multicolumn{11}{|c|}{ 6-year time } \\
\hline \multirow{4}{*}{$\begin{array}{l}07.2007 / \\
12.2012\end{array}$} & 20 & 2.71 & 0.98 & 3.69 & 1.36 & 1.72 & 3.04 & 27.68 & 31.03 & 1.12 \\
\hline & 30 & 3.49 & 0.97 & 4.43 & 1.27 & 2.12 & 3.94 & 47.45 & 53.63 & 1.13 \\
\hline & 40 & 4.18 & 0.98 & 5.16 & 1.24 & 2.30 & 4.72 & 75.56 & 84.55 & 1.12 \\
\hline & 50 & 4.67 & 0.97 & 5.70 & 1.22 & 2.36 & 5.27 & 102.94 & 113.94 & 1.11 \\
\hline Average & & & & & 1.26 & & & & & 1.12 \\
\hline \multicolumn{11}{|c|}{ Site 2,Matishi. Metrological mast } \\
\hline \multirow{6}{*}{$\begin{array}{l}04.2009 / \\
04.2013\end{array}$} & 10 & 2.72 & 0.70 & 3.78 & 1.39 & 1.63 & 3.05 & 30.15 & 33.11 & 1.10 \\
\hline & 20 & 3.28 & 0.70 & 4.34 & 1.32 & 1.85 & 3.70 & 45.09 & 50.19 & 1.11 \\
\hline & 30 & 3.63 & 0.74 & 4.66 & 1.28 & 2.01 & 4.10 & 55.82 & 62.28 & 1.12 \\
\hline & 40 & 4.02 & 0.72 & 5.02 & 1.25 & 2.19 & 4.54 & 69.83 & 78.03 & 1.12 \\
\hline & 50 & 4.38 & 0.73 & 5.37 & 1.23 & 2.31 & 4.94 & 86.08 & 95.30 & 1.11 \\
\hline & 60 & 4.65 & 0.73 & 5.67 & 1.22 & 2.34 & 5.25 & 102.31 & 112.05 & 1.10 \\
\hline Average & & & & & 1.28 & & & & & 1.11 \\
\hline \multicolumn{11}{|c|}{ Site 3, Ventspils. Lidar ZephIR } \\
\hline \multirow{7}{*}{$\begin{array}{l}06.2011 / \\
05.2012\end{array}$} & 44 & 3.71 & ---- & 5.05 & 1.36 & 1.75 & 4.17 & 69.39 & 79.06 & 1.14 \\
\hline & 60 & 5.84 & 0.49 & 7.26 & 1.24 & 2.26 & 6.60 & 208.90 & 235.31 & 1.13 \\
\hline & 80 & 7.19 & 0.59 & 8.81 & 1.23 & 2.32 & 8.11 & 379.61 & 420.97 & 1.11 \\
\hline & 81 & 7.34 & 0.39 & 8.94 & 1.22 & 2.38 & 8.29 & 397.77 & 438.96 & 1.10 \\
\hline & 100 & 8.41 & 0.30 & 10.21 & 1.21 & 2.37 & 9.49 & 598.55 & 655.33 & 1.09 \\
\hline & 130 & 9.38 & 0.10 & 11.37 & 1.21 & 2.36 & 10.59 & 834.35 & 903.95 & 1.08 \\
\hline & 160 & 9.91 & 0.12 & 11.97 & 1.21 & 2.38 & 11.18 & 975.63 & 1056.1 & 1.08 \\
\hline Average & & & & & 1.24 & & & & & 1.11 \\
\hline
\end{tabular}

\section{ESTIMATION OF THE ELECTRICAL ENERGY OUTPUT BY WIND TURBINE BASED ON THE WIND SHEAR DATA}

The calculation of the annual average electrical energy production based on the extrapolation method is exemplified by a $3000 \mathrm{~kW}$ wind turbine of the Vesta 112-3.0 type with a $112 \mathrm{~m}$ high tower. To do this, we used the distribution curves of Weibull's coefficients $k$ and $c$ in dependence on the measurement height at site 2 (Fig. 14). Approximation of these coefficients by means of the power low function allows extrapolation of their relevant functions for heights up to $200 \mathrm{~m}$. 


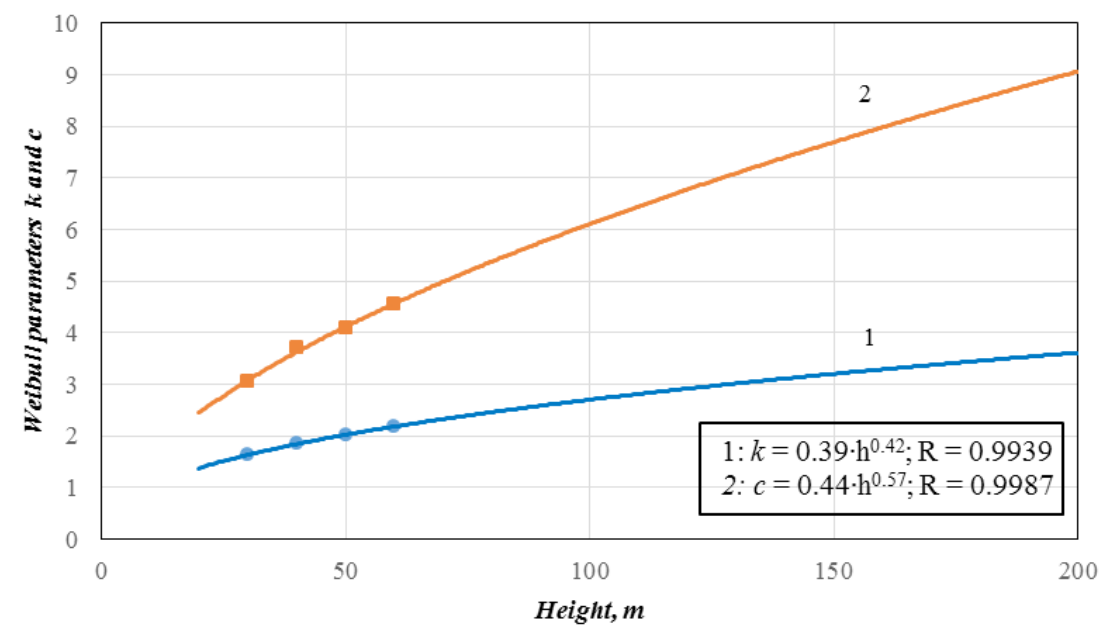

Fig. 14. Distribution of Weibull parameters $k$ and $c$ vs. the measurement height at site 2 and their extrapolation up to height $200 \mathrm{~m}$.

The amount of electrical energy $W(V)$ to which the wind stream energy can be converted with the help of wind turbine in a definite period of time is determined by the equality:

$$
W(V)=P(V) \cdot F(V),
$$

where the values of function $P(V)$ are corresponding to the power curve for generator, while those of function $F(V)$ - to the Weibull's wind speed frequency distribution curve at the height of wind turbine location and respective wind speeds $V(\mathrm{~m} / \mathrm{s})$.

Figure 15 shows the curve of wind stream energy converted into the electrical energy $W(V), M W h$ calculated by equality (3), where function $P(V), k W h$, corresponds to the power curve for a Vesta 112-3.0 generator, while $F(V)$ - to the Weibull wind speed frequency distribution curve for site 2 at height $112 \mathrm{~m}$.

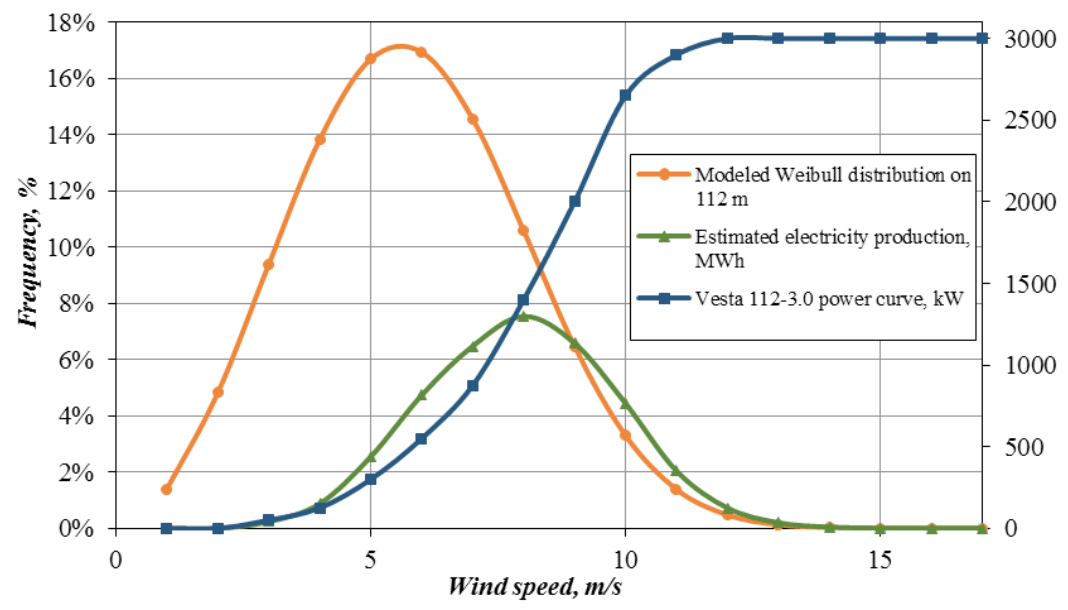

Fig. 15. Power curves of $3000 \mathrm{~kW}$ Vesta 112-3.0 generator, $\mathrm{kW}$, and Weibull's probability density function for wind speeds $\mathrm{V}, \mathrm{m} / \mathrm{s}$ at height $112 \mathrm{~m}$ characterizing the electrical energy production, $M W h$. 
The integral of function $W(V)$ for the time of $8760 \mathrm{~h}, W_{\text {avg. }}$ Weibull $=6276 \mathrm{MWh}$, corresponds to the maximum per year electrical energy that could be produced by the wind turbine under consideration. In this case, its operational efficiency can be characterized by coefficient $C_{a}$ equal to the ratio of the calculated electrical energy output to the installed power of a generator at its non-stop running for a year, i.e.:

$$
C_{\text {eWeibull }}=\frac{6278}{3 \cdot 8760} \cdot 100 \%=23.9 \% .
$$

In turn, the calculated average cubic wind speed $V_{\text {avg.cub. }}$, equal to $6.75 \mathrm{~m} / \mathrm{s}$ according to the curve in Fig. 11 for the height of $112 \mathrm{~m}$, site 2, allows determination of the generator power by the relevant curve in Fig. 15: for the mentioned wind speed $P(V)=794 \mathrm{~kW}$. In this case the amount of electrical energy produced in the time $T=8760 h$ will be:

$$
W_{\max \text { avg.cub. }}=0.794 \cdot 8760=6^{\prime} 953 \mathrm{MWh} .
$$

The efficiency of wind turbine operation calculated by the method for determination of the annual average generator power corresponding to the average cubic wind speed value is:

$$
C_{e \text { avg.cub. }}=\frac{6953}{3 \cdot 8760} \cdot 100 \%=26.5 \%,
$$

i.e. greater by $11 \%$ than that obtained by expression (4).

Therefore, the average cubic wind speed value can be used for estimation of the wind turbine operational efficiency in a first approximation. This, in turn, means that the wind energy potential of particular regions can be estimated based on the results of long-term measurement data of MetStations obtained for the height of $10 \mathrm{~m}$.

\section{CONCLUSIONS}

- For efficient use of wind energy in the territory of Latvia the reliable information is needed on the relevant energy distribution at heights up to $200 \mathrm{~m}$.

- The measured average cubic wind speed values $\left(V_{\text {avg.cub. }}\right)$ consistently exceed those of average speed $\left(V_{\text {avg. }}\right)$ - more than by $25 \%$, independently of the measurement duration and site.

- The results for the wind energy density calculated using the modelled Weibull's distribution function consistently differ by $10 \%$ from those of long-term monitoring of factual wind speed fluctuations, independently of the measurement duration and site.

- The amount of electrical energy production by the wind turbine which is estimated using the measured average cubic wind speed values does not exceed $11 \%$ as compared with the results obtained based on the Weibull distribution. Therefore, to estimate the operational efficiency of wind turbine in a first approximation the average cubic wind speed values can be taken. 
- In the territory of Latvia, 24 State MetStations are functioning, which over many years carry out the wind speed records at a height of $10 \mathrm{~m}$ above ground and possess a relevant database on the average wind speed values in a long term. These data can be employed to estimate the potential of wind energy at heights up to 200 $m$, provided there are results of short-term verifying measurements for heights exceeding $30 \mathrm{~m}$ obtained with the help of a lidar or a mast.

\section{ACKNOWLEDGEMENTS}

This paper was supported by European Social Fund project "Assessment of wind energy potential in Latvia and environmental impact from wind energy installations", No. 2014/0010/1DP/1.1.1.2.0/13/APIA/VIAA/033.

\section{REFERENCES}

1. Shipkovs, P., Bezrukovs, V., Bezrukovs, V.l., Pugachevs, V., \& Silutins, V. (8-13 May, 2011). Measurements of the wind energy resource in Latvia. World Renewable Energy Congress WREC, Sweden, Linköping, 0724 WE.

2. Bezrukovs, V., Bezrukovs, V.1., \& Levins, N. (Oct. 2011). Problems in assessment of wind energy potential and acoustic noise distribution when designing wind power plants. The 52 $2^{\text {nd }}$ International Scientific Conference: Power and Electrical Engineering. Scientific journal of Riga Technical University, 13. Series „Environmental and Climate Technologies", Vol. 6, Riga, 9-16.

3. Komashilovs, V., Zacepins, A., Bezrukovs, V., Bezrukovs, D., \& Hofmanis, J. (2014). Web application for processing and analysis of the raw wind measurement data. In: Proceedings of 15th IEEE International Symposium on Computational Intelligence and Informatics (CINTI 2014), 455-458.

4. Bezrukovs, V., Bezrukovs, V.1., \& Lizuma, L. (May 30-31, 2013). The landscape influence on the wind energy distribution in height on the Latvian coast of the Baltic Sea. International Conference on Alternative Energy in Developing Countries and Emerging Economies. Thailand (Bangkok), $614-619$.

5. Bezrukovs, V., \& Bezrukovs, V.1. (May 13-17, 2012). Wind speed and energy at different heights on the Latvian coast of the Baltic Sea. WREF, Denver (Colorado), 13-17.

6. Bezrukovs, V., Bezrukovs, V.I., \& Zacepins, A. (2014). Comparative efficiency of wind turbines with different heights of rotor hubs: performance evaluation for Latvia. Journal of Physics, Conference Series, 1-9.

7. Manwell, J.F., McGowan, J.G., \& Rogers, A.L. (2009). Wind Energy Explained: Theory, Design and Application. John Wiley \& Sons Ltd. 


\title{
VĒJA PARAMETRU UN VĒJA ENERGIJAS POTENCIĀLA NOVĒRTĒJUMS BALTIJAS JŪRĀ, LATVIJAS REĢIONĀ
}

\author{
V. Bezrukovs, V1. Bezrukovs, A. Zacepins, V. Komashilovs
}

Kopsavi $1 \mathrm{kums}$

Zinātniskais raksts ir veltīts pētījumam par vēja enerǵijas potenciālu Latvijas teritorijāa, Baltijas jūras piekrastē, balstoties uz ilgtermiņa vēja ātruma un vēja enerǵijas blīvuma svārstību novērojumiem no 10 līdz 160 metriem augstumā. Vēja àtruma un vēja virziena mērījumu dati tika iegūti un apkopoti statistiskajā datubāzē laika periodā no 2004 līdz 2013. gadam, izmantojot mērīšanas sistēmu LOGGER 9200 Symphonie, kas bija ierīkotā uz 60 metru augsta masta - viena rietumu piekrastē un otra Latvijas ziemel̦u-austrumos. No 2011. gada jūnija līdz 2012. gada maijam mērījumu datubāze tika papildināta ar datiem, kas tika iegūti ar lidaruZephIR augstumos no 40 līdz 160 metriem, un datiem no „Latvijas Vides, ǵeologijas un meteorologijas centra" tam pašam laika periodam. Analizējot mērījumus 2007. g.-2013. g., grafiki ar vēja sezonālām ātruma svārstībām tika iegūti līdz 160 metru augstumam. Pētījuma rezultāti par vēja ātruma sadalījumu līdz 200 metriem, l̦auj novērtēt vēja enerǵijas potenciālu Latvijā, un tiem ir jāpalīdz noteikt perspektīvākās vietas vēja turbīnu izvietošanai.

09.02.2015. 